\title{
Reviving urban spaces through tactical urbanism in baghdad: Five common tactics
}

\author{
Dr.Shaimaa Hameed Hussein ${ }^{1}$, Dr.Samah A. Abrahem ${ }^{2}$ \\ ${ }^{1}$ Architecture Dept., Al-Nahrain University, Iraq \\ ${ }^{2}$ Construction and Projects Dept., Al-Nahrain University, Iraq
}

\section{Article Info}

Received Dec. 18, 2018

\section{Keyword: \\ Tactical urbanism \\ Baghdad \\ Urban spaces}

\begin{abstract}
This research investigates the socio-spatial causes and consequences of tactical urbanism practices in Baghdad. It attempts to identify the main creators of these practices and their motivations. It recognizes five common practices of tactical urbanism in Baghdad, public art, pop-up rest areas, pavement plazas, guerrilla gardening, and open streets. This research argues that the applications of tactical urbanism in Baghdad could revive urban spaces and positively impact local communities, and that it could have various implications for urban policies. This article examines evidence from fieldwork and interviews with individuals involved in tactical urbanism projects. It also employs a questionnaire which addresses the opinions of individuals in the profession of architecture and urban design regarding the impact of tactical urbanism.
\end{abstract}

\section{Corresponding Author:}

First Author,

Architecture Departement,

Al-Nahrain University, Iraq

Email: shaimaahameed@yahoo.com

\section{Introduction}

Despite the existence of historical precedents, the term tactical urbanism, also commonly known as popup urbanism, everyday urbanism, and guerilla urbanism, is relatively new in the profession of urban design and the planning discourse. During the early 2000s, several of its applications in post-industrial Europe were explored by the Berlinbased Studio Urban Catalyst. Yet, it gained popularity as a term in scholarly and academic writings in 2010-2011 after the publication of Tactical Urbanism: Short-term Action, Long-term Change, which addressed various projects of tactical urbanism in several locations in North America. As a movement, tactical urbanism has gained momentum and popularity in the planning discourse and became one of the top planning trends of 2011[1].

The applications of tactical urbanism feature several common characteristics which can be described as smallscale improvements, short-term, unauthorized, creative, and intentionally functional. While large scale developments to urban fabric is the responsibility of official or governmental efforts, small-scale improvements might be a way for individuals to refine their built environment and increase its viability without the need for gaining legalization or authorization. It is considered as a way of testing new approaches to urban design before making substantial changes in urban policies which require financial and political commitments. [2] Therefore, applications of tactical urbanism are usually, "bottom-up citizen-led actions filter up and have the power to fundamentally change the institutions in even the most challenging settings." [3] Its creators could be citizen activists, community groups, neighborhood organizations, non-profit, organizations. [4] Yet, it could involve city officials and municipal departments if applied as temporary pilot projects to test new policies. [5]

While testing new concepts or policies is a prime cause or motivation for employing tactical urbanism, it is not the only one. Some interventions in urban spaces are claimed to involve political expression, establish a call for radical changes, express resistance, or resilience towards certain socio-political actions; other 
interventions are described as acts of personal or artistic self-expression. [6] However, the latter might still count as an improvement to abandoned or unused urban spaces. Such actions add a sensation of familiarity and domestication to urban spaces. [7] Some intervention which might be understood as vandalism or convey an image of a pointless, or even a juvenile act. [8] Hence, not all urban interventions lead to a successful end. Yet, it could provide a creative short-term solution for an everyday need, with a long-term change in mind. Applications of tactical urbanism have been increasingly noticed in various parts of the world. Many examples in several cities have been addressed in literature. This article focuses exclusively on identifying the applications of tactical urbanism in Baghdad, the capital city of Iraq. Despite its noticeable and wide-ranging examples in Baghdad, the term 'tactical urbanism' as well as its applications are still missing in the writings of local Iraqi scholars and academics. Therefore, this paper is an attempt to identify and investigate the most common practices of this urban trend in Baghdad. It sheds the light on several examples with an emphasis given to the key players involved in this practice and their motivations.

\section{Five Common Tactics}

During the fieldwork related to this research in Baghdad, several tactical urbanism applications were noticed. The most common applications can be divided into five categories, public art, pop-up rest areas for the groups of worshippers known locally as (Mawakib), pavement plazas encompassing trade show booths or (bastiyat), guerrilla gardening, and open streets for sporting events.

\subsection{Public Art and the Sense of Resilience}

Public art is an umbrella term which encompasses a vast range of practices and forms such as sculptures, temporary artworks, monuments, memorials, earthworks, street furniture, and so on. Yet, Public Art, as a term, is relatively new as it was coined in the USA and UK during the late 1960s. [9] Its motivations varies from activism and political resistance to self-expression of artistic abilities, and visual documentation of historical events and experiences. [10] It can thus, play a political role and is considered as and a tool for change.

During the recent decade, public art has been widely increasing in the urban scenery of Baghdad city. It can mostly be seen on the surfaces of the high concrete barriers which line up the main streets. These barriers were introduced to the urban scenery during the years that followed the war of 2003 in Iraq. During which, Baghdad witnessed an increasing rate of crime and terrorist attacks, in addition to a growing presence of armed militiamen. [11] As a security measure, high concrete barriers were installed by the government around entire neighborhoods, and around government buildings with limited and secured accesses. Several local Iraqi scholars and academics have drawn attention to the negative socio-spatial impact and implications of these solid barriers which transformed Baghdad into a city of walls. Some literature described them as symbols of fortification, socioeconomic hierarchy, and ethnic segregation. [12] Others have addressed the problematic impact of these barriers on facades of the main streets, especially in the traditional districts of Baghdad city. [13]

Nonetheless, these concrete barriers have provided a platform for artists and advocators to express their sense of resilience towards walling and gating off neighborhoods in Baghdad. They deliver messages of peace and shed light on crucial socio-political issues in Iraq such as ethnic diversity, civic violence, and terrorism. A good example is Imprint of Hope, 'Basmateamel' which is an independent, non-profit, non-governmental Iraqi youth Organization for human development. It includes over 300 volunteers. Their drawings focus on issues such as the need for peace and unity amongst the various ethnic and religious groups in Iraq, as well as the importance of heritage and historical symbols (See figure 1). Their drawings target important locations in Baghdad which deliver their messages to a wide range of social, religious, and educational backgrounds. Such as the wide surfaces of the concrete barriers near and around universities and the barriers on the main streets and roundabouts, the walls under the bridges, and the fences and walls of schools.

Several journalists have commended public art in Baghdad and the independent initiatives of groups such as Basmateamel. For instance, in an article entitled "Iraqis Defy Sectarianism through Urban Planning, Art" published by the Middle East Institute on August 30, 2016, the journalist pointed out the way public art has become a symbol of hope, unity, and solidarity in Baghdad. Public art has become an expression of resilience against the spread of concrete barriers and a cry for the need to eliminate their negative impact on the urban scenery of Baghdad city. 


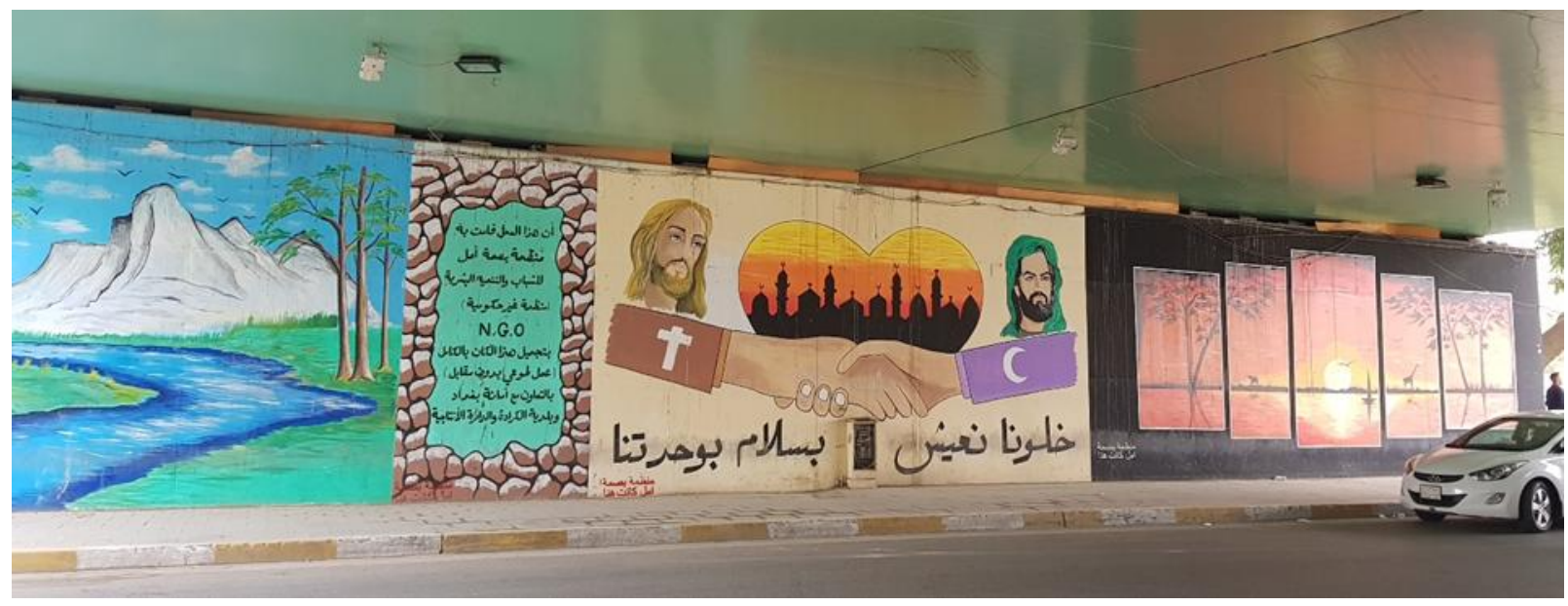

Figure1. Public art created by Basmateamel on the walls under Jadriya Bridge near the entrance of Al-Nahrain University delivering a message of peace and unity amongst different religions in Iraq.

Source: Authors

\subsection{Pop-up rest areas (mawakib)}

These spaces pop-up temporarily in various locations in Baghdad city during certain annual religious events such as, Ashuraa' or Muharram mourning ceremonies during the days of mourning which mark the anniversary of the Martyrdom of Imam AL-Hussain (AS), and the anniversary of the Martyrdom of Imam Musa Al-Kadhim (AS).

Such ceremonies and events have been widely practiced publicly since the end of the Ba'athist regime in Iraq. They are sponsored, or financed by various entities, including government-affiliations, political parties, emergent community groups, as well as citizens willing to provide voluntary service to worshippers participating in religious ceremonies.

During these events, several main streets are converted to walkable social spaces through the exploitation of barriers and military check-points as part of a security strategy taken by the government to block the streets surrounding or leading to certain religious shrines. These measurements ensure the safety of people participating in religious ceremonies. Temporary tents and street furniture such as tables, and chairs pop-up to transform these blocked streets into walkable urban spaces, informal, temporary social spaces, rest areas, and gathering spaces. These spaces offer food and even lodging to the visitors and worshippers walking from Baghdad towards Imam Al-Hussain shrine in Karbala city. They bring people together and celebrate a sense of inclusion.

Good examples of these pop-up rest areas can be observed in the temporary rest areas created on streets surrounding the shrine of Imam Al-Khadum (see figure 2). Other examples include the annual pop-up rest areas on Al-Qanat Street, and Muhammed Al-Qassim Street during the days of mourning.

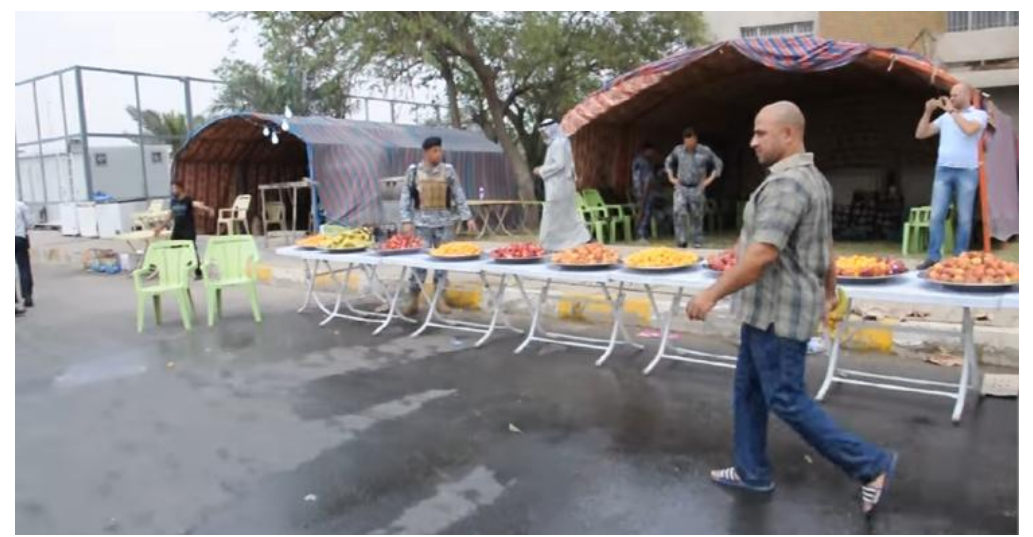

Figure2. Pop-Up rest areas during Muharram in Palestine Street in Baghdad. Temporary tent structures and street furniture placed on the sidewalk and the side of a main street by Ahmed Al-Hasani, a citizen who volunteered to provide rest areas for the worshippers commemorating Imam Moussa al-Kadhim.

Source: Authors 


\subsection{Pavement Plazas}

Pavement plazas are created by converting space on the sidewalks of main streets to usable pedestrian plaza or commercial space. This type of tactical urbanism is popularized in the commercial streets in Baghdad city such as Karrada Street, Palestine Street, Siham Mitwalli Street in Al-Adhamia, and others (See figure 3). It combines various tactics from pop-up stores, or pop-up retail to pop-up cafes, and food carts. They reach their peak during evening hours as they reduce the impact of cars and provide temporary safe spaces for shopping, walking, and social activities. In addition, they promote local businesses and local economic development for they are created by individuals who make living from these pop-up spaces.

Several examples of pavement plazas can be observed in Baghdad. For instance, the pop-up retail stores which are set up in vacant spaces on the pavement of Karrada Street during the evening. These spaces extend to occupy the spaces on the blocked streets such as Al-Attar Street which was blocked by barriers as part of a national security strategy which was initiated after the war of 2003 in Iraq as counterinsurgency plan. In addition to pop-up stores, Karrada Street involves pop-up cafes which are temporary outdoor sitting spaces or eating areas to contain the overflow of customers of a nearby restaurants or a cafe.

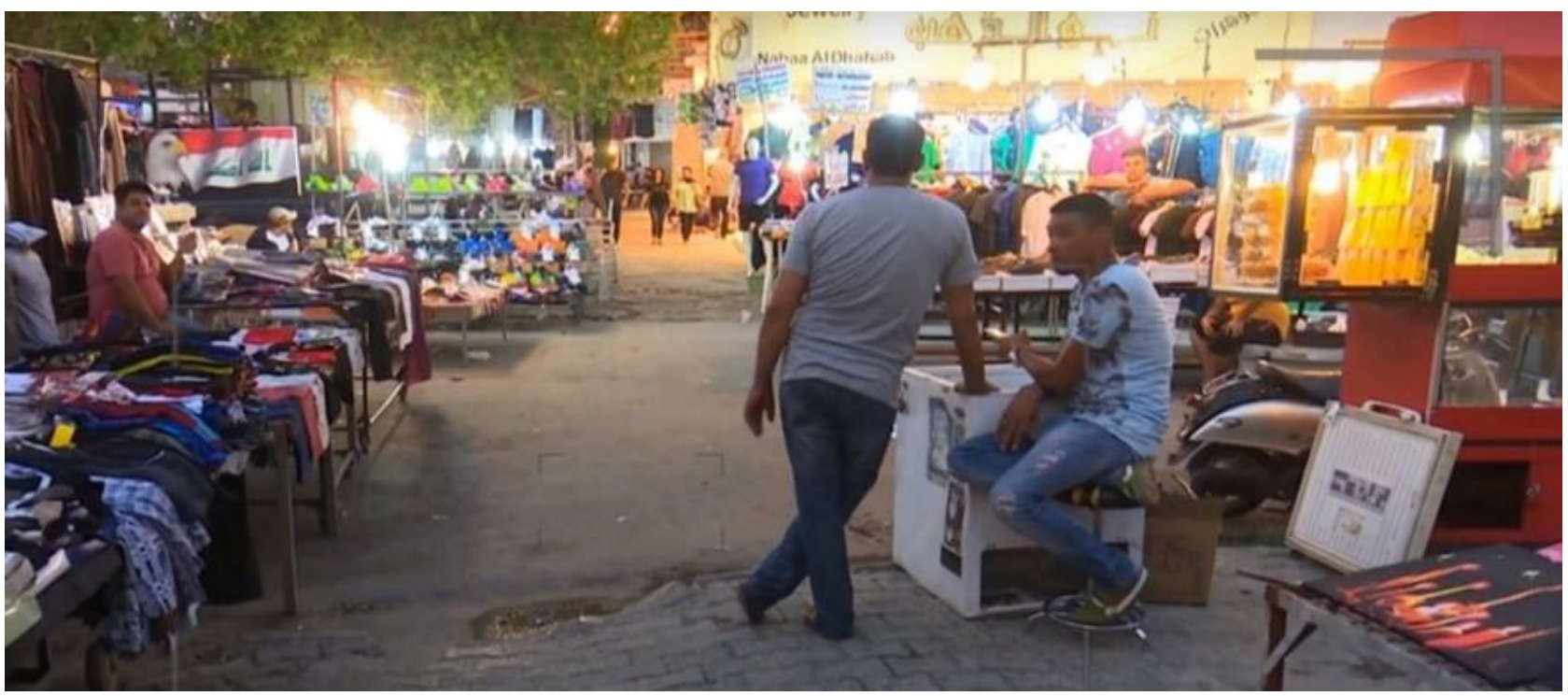

Figure3. Pavement plaza/ bastiyat in Karrada Street in Baghdad.

Source: Authors

\subsection{Guerrilla gardening}

Guerrilla gardening or greening is planting or cultivating and functionally transforming unused land or abandoned sites, facades or infrastructure. [14] It is thus, an unauthorized act by individuals or a community group. This type of tactical urbanism is based solely on individual efforts. It can be described as illegal and informal. Yet, it could be financially beneficial to the individuals who created it. While visual improvement of a vacant land is one of the benefits of guerrilla gardening, financial profit can be the prime motivation. A good example of this application of tactical urbanism can be seen in Ghazalia district in Baghdad (See figure 4). A community group from in Aldulaee neighborhood managed to clear the rubble from an unused site on the side of the road and cultivated edible plants to be harvested later and sold in the market for financial gain. Other examples include the transformation of vacant lots in Sab'abkar neighborhood into plant nurseries. 


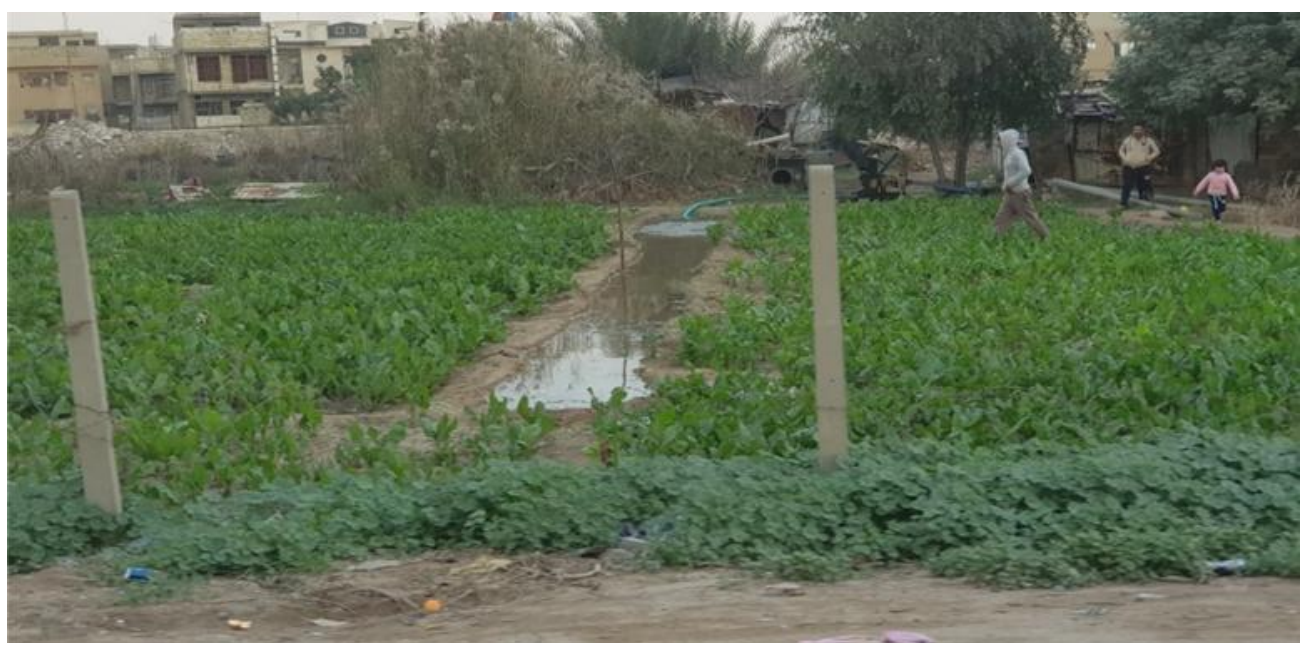

Figure4. Guerrilla gardening in Aldulaee neighborhood in Ghazalia district in Baghdad, created by individuals on the road shoulder on what used to be vacant spaces covered with rubble.

Source: Authors

\subsection{Open streets}

The initiation of an annual Baghdad marathon for peace in 2015 has marked the beginning of a new strategy of tactical urbanism in Baghdad. This strategy can be described as open street. It provided a temporary answer to a local need for the provision of safe streets and urban spaces for all the participants in that marathon by closing off Abu Nuwas street to vehicular traffic (See figure 5). This sporting event was organized by the Iraqi Social Forum in Baghdad with the aim to reject discrimination and violence and to consolidate the culture of peace and citizenship. [15]

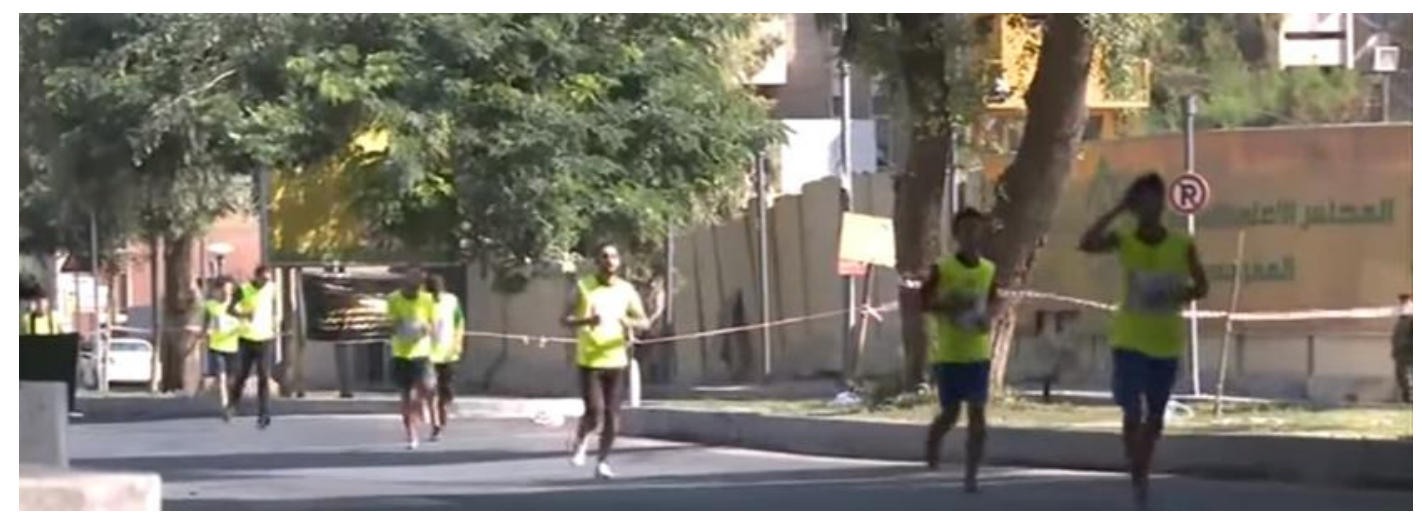

Figure 5. Open street tactic created temporarily by blocking off Abu Nuwas street to provide a safe open space for participants in the annual 'Baghdad marathon for peace'.

Source: Authors

\section{Impact of Tactical Urbanism in Baghdad: Questionnaire Results.}

To further understand the phenomena of tactical urbanism in Baghdad city, an anonymous questionnaire was included in this research (See table 1). [16] It was designed to include the most common tactics, as well as indicators regarding their socio-spatial impact such as their location, timing, and their relationship with pedestrian circulation and vehicular circulation. The questionnaire comprised 32 individuals from the profession of architecture and urban design. $45.2 \%$ of the participants were faculty members from departments of architecture and urban planning from various universities, $29 \%$ were students, and $25.8 \%$ were professionals from outside the academia. 
Table1. The questions included in the anonymous questionnaire.

\begin{tabular}{ll}
\hline General info about the participant & Student, faculty, other \\
\hline Degree & B.Sc, M.Sc, PhD, other \\
\hline What do you think is the impact of the following tactic (positive or negative) \\
\hline 1- Public Art on the concrete barricades \\
\hline 2- Pop-up rest areas on the main streets for the groups of worshippers during religious ceremonies \\
\hline 3- Trade show booths on the pavement of main streets \\
\hline 4- Food carts on the pavement or corners of main streets \\
\hline 5- Temporary outdoor sitting spaces on the pavement of main streets \\
\hline 6- Guerrilla gardening or plant nursery on vacant lots \\
\hline 7- Open streets for sporting events
\end{tabular}

In your opinion which of the above is the most positive

In your opinion which of the above is the most negative

What are the reasons in your opinion: (select all that apply)

Timing, location, its relation with pedestrian circulation, its relation with vehicular circulation

Although the interviews with individuals who rely on some of these tactics for living indicated that they have positive economic impact, results from the questionnaire indicated that most of these tactics are perceived as negative urban phenomena by architects and urban designers as shown in figure 6 below. With the exception of guerrilla gardening, tactical urbanism, as claimed by the questionnaire participants, obstructs both pedestrian and vehicular circulation. From the participants' perspective, the tactic which has the most negative socio-spatial impact on the built environment is the pavement plazas, and especially the trade show booths 'bastiyat' in terms of their timing during the day as well as its location. Guerrilla gardening on the other hand has the most positive impact for it improves the built environment and its locations do not conflict with neither pedestrian nor vehicular circulation (see figure 6,7 ).

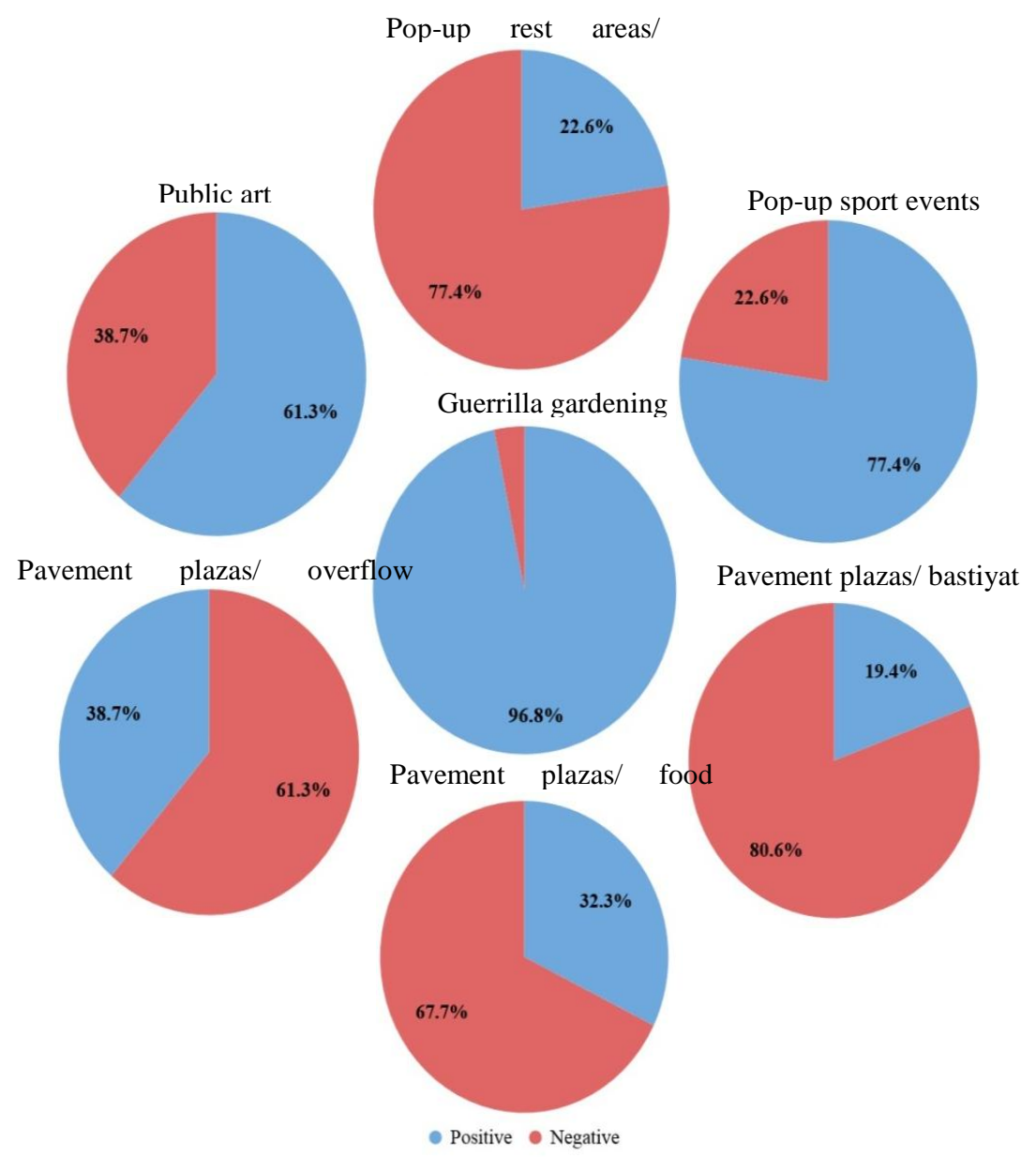

Figure 6. Indicators on the positive/negative impact of the most common tactics in Baghdad. Source: Authors 


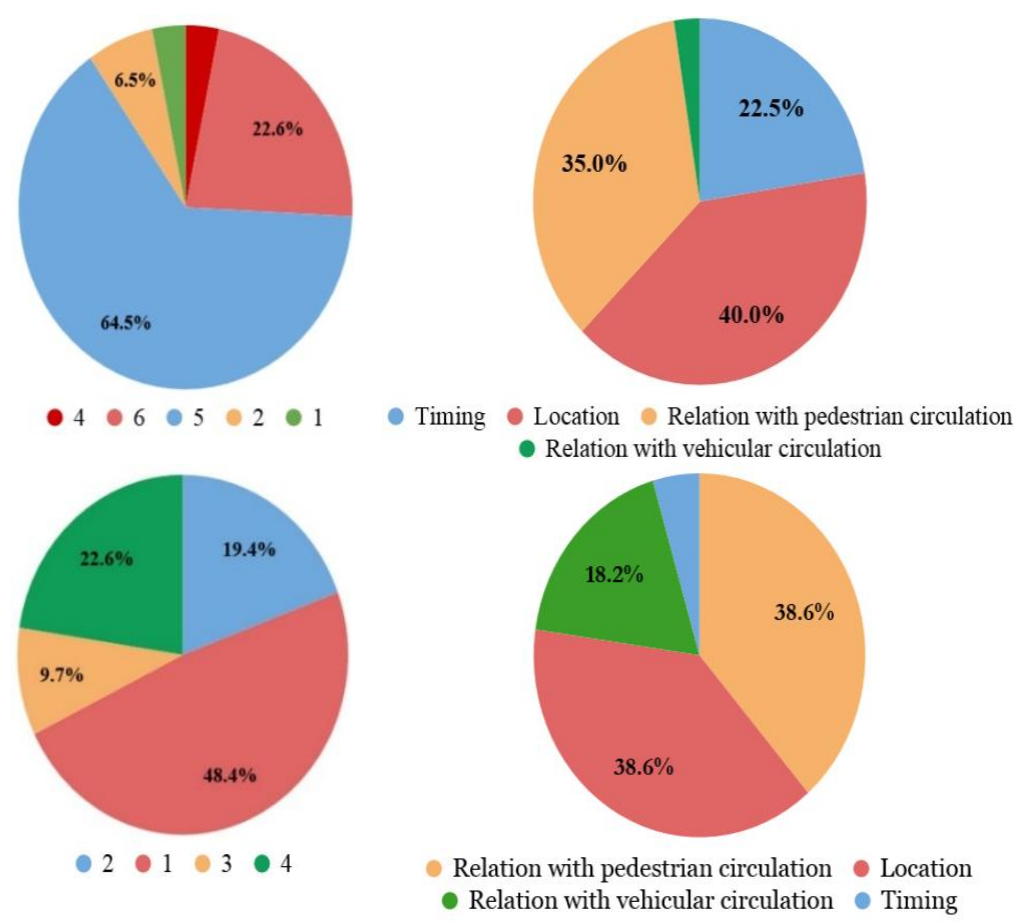

Figure 7. Indicators on the most positive tactic (top left and right), indicators on most negative tactic (bottom left and right). (1) pavement plazas/ bastiyat (2) pavement plazas/ overflow seating (3) pavement plazas/ food carts (4) pop-up rest areas/ mawakib (5) guerrilla gardening (6) open street (7) public art.

Source: Authors

\section{Conclusion}

Although several practices of tactical urbanism were observed during the fieldwork of this research, this research recognizes five common tactics in Baghdad: public art, pop-up rest areas (mawakib), pavement plazas, guerrilla gardening, and open streets. The results from the observations and the interviews indicated that while the creators of these tactics might be share great similarities for they all are citizen-led actions, the motivations of tactical urbanism in Baghdad vary according to the type of these tactics. However, all the resulting tactics provided low-risk, temporary solutions for local needs. They also provided answers to urban design challenges and increased the livability of urban spaces. In addition, they embodied the organizational capabilities of individuals and local communities.

Despite these socio-spatial benefits, results from the questionnaire showed that architects and urban designers perceive these tactics, except for guerrilla gardening, as negative urban phenomena in Baghdad for their obstruction of pedestrian and vehicular circulation. Such dilemma could bring these tactics into public attention, and might thus, has implications on urban policies. However, the continuous widespread of these tactics might be an indication that they might be more of constructive urban strategy than a destructive one within the built environment. Therefore, further research is required to understand how their inclusion in urban policies might mitigate their negative impact on the built environment and increase their socio-spatial benefits.

\section{References}

[1] Feifer, Laura. The Planner's Guide to Tactical Urbanism, Regina Urban Ecology.p.4, 2014.

[2] Mike Lydon and Anthony Garcia, Tactical Urbanism: Short Term Actions for Long Term Change, Island Press: Washington,p.201, 2015. 
[3] Mike Lydon and Anthony Garcia, Tactical Urbanism: Short Term Actions for Long Term Change, Island Press: Washington,p.149, 2015.

[4] Gordon C. C. Douglas, "Do-It-Yourself Urban Design: The Social Practice of Informal "Improvement" Through Unauthorized Alteration," American Sociological Association, p.11, 2013.

[5] Gordon C. C. Douglas, "Do-It-Yourself," 8; Mike Lydon and Anthony Garcia, Tactical Urbanism: Short Term Actions for Long Term Change, Island Press: Washington,p.14, 2015.

[6] Gordon C. C. Douglas, "Do-It-Yourself Urban Design: The Social Practice of Informal "Improvement" Through Unauthorized Alteration" p.6.

[7] Chase, John, Margaret Crawford, and John Kaliski. 2008. Everyday urbanism. New York: Monacelli Press, p.22.

[8] Gordon C. C. Douglas, "Do-It-Yourself Urban Design: The Social Practice of Informal "Improvement" Through Unauthorized Alteration" The University of Chicago, p.6.

[9] The term was associated with government Per Cent for Art programmes (introduced in Ireland in 1987), which provide funds for a public artwork linked to capital development

[10] Suzanne Lacy, Mapping the Terrain: New Genre Public Art, Bay Press Seattle: Washington, 1995.

[11] Mona Damluji, "Securing Democracy in Iraq," TDSR xxi, no. 11, pp.71-85, 2010.

[12] Ahmed Abdul Majeed, "Crisis of Professional Responsibility in the Press of Iraq after the War," Baghdad University Press (2007): 1; R. Chandrasekaran, Imperial Life in the Emerald City Inside Iraq's Green Zone, 2006; A. Mohamed, "The American Strategy and its Impact on the Social and Security Situation in Iraq," 2008; N. Ibrahim, "The Phenomenon of Violence and Sectarian Polarization in Iraq after 2003," 2015; K. Ahmed and A. ALBustany, "Crime Provokes Civil War and Sectarian Fighting," 2015; Al-Qarawee, "Iraq's Sectarian Crisis: A Legacy of Exclusion," 2014; S. Abbas, "Analytical Study of Factors Associated with Iraqi Family Disintegration after the Events of 2003/4 /9," 2012; Y. Aubed, "Terrorism and its Implications for Security and Social Peace," 2016.

[13] M. Al-Hasani "Urban Space Transformation in Old City of Baghdad," 2012.

[14] Gordon C. C. Douglas, "Do-It-Yourself Urban Design: The Social Practice of Informal "Improvement" Through Unauthorized Alteration" The University of Chicago, p. 6.

[15] Visconti, Nicola. "Baghdad Marathon For Peace Is a Reality." Iraqi Civil Society Solidarity Initiative (ICSSI), p.1, Sep 29, 2016.

[16] The anonymous questionnaire was created and shared using google docs which is available from http://docs.google.com/forms/d/1kppanvkb7lbiuy9dkmekjs7fg5_yn-bmbo8vyxqtpkw/edit. 